\title{
Does ozone treatment of maize seeds influence their germination and growth energy?
}

\author{
Dmitry NORMOV ${ }^{1}$, Evgenii CHESNIUK ${ }^{1}$, Andrey SHEVCHENKO ${ }^{1}$, Tatiana NORMOVA ${ }^{1}$, Raisa \\ GOLDMAN $^{1}$, Denis POZHIDAEV ${ }^{1}$, Tanja BOHINC ${ }^{2}$, Stanislav TRDAN ${ }^{2,3}$
}

Received August 07, 2019; accepted November 05, 2019. Delo je prispelo 07. avgusta 2019, sprejeto 05. novembra 2019.

\begin{abstract}
Does ozone treatment of maize seeds influence their germination and growth energy?

Abstract: This article evaluated the pre-sowing treatment of seeds with electroozonation. A full factor experiment on the influence of the parameters of the technological process of electroozone treatment on the sowing qualities of maize seeds was carried out. Based on the experimental data, the effect of ozone concentration, treatment time and the time before sowing and after treatment on the germination ability, germination energy and growing energy of maize seeds was determined. According to the results of the study, the corresponding regression equations were calculated, graphical dependencies were constructed and method parameters for the pre-sowing treatment of maize seeds with ozone were determined.
\end{abstract}

Key words: electroozonation; ozone; treatment time; ozone concentration; time before sowing; maize seeds; germination ability; germination energy; growing energy.
Ali tretiranje semena koruze $\mathrm{z}$ ozonom vpliva na njegovo kalitev in energijo kalivosti?

Izvleček: Prispevek obravnava tretiranje semena koruze pred setvijo z elektroozoniranjem. V njem so predstavljeni rezultati faktorskega poskusa vpliva različnih dejavnikov tehnološkega procesa elektroozoniranja na dejavnike kakovosti semena koruze. V tej zvezi so predstavljeni vplivi koncentracije ozona, časa tretiranja z ozonom in časa pred setvijo (po tretiranju z ozonom) na odstotek kalitve, energijo kalivosti in energijo rasti semena koruze. Ob upoštevanju rezultatov raziskave so izračunane regresijske enačbe, izdelani grafični prikazi in predstavljeni ključni parametri semena koruze, tretiranega $\mathrm{z}$ ozonom pred setvijo.

Ključne besede: elektroozoniranje; ozon: čas tretiranja; koncentracija ozona; čas pred setvijo; seme koruze; odstotek kalitve; energija kalivosti; energija rasti

1 Kuban State Agrarian University, Ulitsa Kalinina 13, Krasnodar, Krasnodarskiy kray, 350004, Russia

2 University of Ljubljana, Biotechnical Faculty, Dept. of Agronomy, Jamnikarjeva 101, SI-1000 Ljubljana

3 Corresponding author, e-mail: stane.trdan@bf.uni-lj.si 


\section{INTRODUCTION}

To increase production and improve the quality of crop production, it is necessary to reduce crop losses from diseases, various pests, and weeds. Pre-sowing treatment of planting material is of great importance in the intensive system of crop production. Today, the main process of pre-sowing treatment of seeds is sterilization aimed at destroying external and internal infections. Despite the external effectiveness of the use of chemical processing methods, they have a number of serious drawbacks. The use of chemicals is associated with danger to humans and environmental pollution (Yeoh, 2014). The development of new alternative seed treatment methods is therefore an important scientific task. During the 1930s to 1940s, professor Chizhevsky systematized and substantiated the positive effect of the use of charged particles of oxygen and ozone when exposed to living organisms and plants (Chizhevsky, 2015).

Ozone $\left(\mathrm{O}_{3}\right)$ is a chemically highly reactive compound that is an allotropic form of oxygen with powerful oxidizing properties. Ozone ranks highly in reactivity, second only to fluorine (Normov, 2003). Moreover, unlike other oxidizing agents, in the process of chemical reactions, ozone decomposes into molecular and atomic oxygen and limiting oxides that do not pollute the environment and do not lead to the formation of carcinogenic substances, such as oxidation products of chlorine or fluorine (Booker, 2009).

Despite the relatively large number of publications devoted to the use of ozone, its antibacterial and stimulating properties have not been fully studied; therefore, the purpose of our study was to determine the effect of ozone on the sowing qualities of seeds.

\section{MATERIALS AND METHODS}

Under laboratory conditions, germination energy, germination ability and growing energy were determined. The standard method stipulates that in seed control laboratories, the germination ability of maize is determined at a constant temperature of $+20^{\circ} \mathrm{C}$. One hundred seeds were germinated in a germinative bed with sand moistened to full capacity. The experiment was conducted with four replicates. Germination energy was determined on days 3-4, and the germination ability (the number of seeds that gave normal seedlings in $\%$ of 100 planted) was determined between days 7 and 10 (Dospehov, 1985).

Seedlings with a well-developed root, equal to or more than the length of a seed, and a stem with a size of half a seed were considered normal and were used in the experiment. Seeds that had only a shoot or root were considered to not have successfully germinated, as were those that were sick, misshapen, rotten, or split. There were many "hard" seeds among the freshly harvested maize seeds. These seeds with a hard pericarp did not swell and did not germinate; by spring, their number decreased. Therefore, the seed germination ability of the maize was determined two months before sowing.

We proposed a new accelerated method for determining the sowing qualities of seeds in rolls. This method makes it possible to visualize and examine the influence of the physical method of ozone exposure (ozone) on the development of seedlings to accelerate the experimental results.

Dry seeds (100 pieces in each batch) were laid out on a film covered with a layer of filter paper. The size of the strip was $25 \times 100 \mathrm{~cm}$. The paper was moistened with water. Seeds were placed at a distance of $5 \mathrm{~cm}$ from the top edge and $1 \mathrm{~cm}$ from each other. It was covered with the same roll of filter paper and formed into a roll.

The seed roll was placed vertically in a $250 \mathrm{~cm}^{3}$ tank, which was then filled completely with water. The seeds germinated in a ventilated chamber at a constant temperature of $28-30{ }^{\circ} \mathrm{C}$. Germination energy was determined on the second day, and germination ability was determined on the sixth day.

The seeds were inspected on the sixth day. Rotten seeds and seeds that gave abnormal shoots were removed. The upper layer of the filter paper was replaced with a new layer. During the day, the room was aired. The growing energy was determined on the 10th day: length of the seminal root and the shoot, the total length of the seedling, and the mass of 100 seedlings were measured. The growing energy of seedlings was evaluated visually by the length and thickness of the seminal root, the intensity of development and the mass of the seedling.

The seeds were treated according to the following scheme: four levels of ozone concentration X2 (10, 24, $48,72 \mathrm{mg} \mathrm{m}^{-3}$ ) with four levels of treatment time X1 (3, $5,7,9$ minutes.). Then, the seeds were planted after four equal intervals of time X3 (1, 10, 20, 30 days).

For the measurement of the ozone concentration, we chose the iodometric method. This method has been used to measure the concentration of ozone in the air at a content of $4-10 \%$.

The iodometric method for measuring the concentration of ozone in a gas is as follows: ozone-containing gas is passed through a solution of potassium iodide and sulfuric acid. As a result of the chemical interaction of ozone with potassium iodide, an equivalent amount 
of free iodine is released according to the following equation:

$$
\mathrm{O}_{3}+2 \mathrm{KJ}+\mathrm{H}_{2} \mathrm{SO}_{4}=\mathrm{J}_{2}+\mathrm{K}_{2} \mathrm{SO}_{4}+\mathrm{O}_{2}+\mathrm{H}_{2} \mathrm{O}
$$

The iodine released in this reaction is titrated with sodium sulfate (sodium thiosulfate) according to the equation below:

$$
2 \mathrm{Na}_{2} \mathrm{~S}_{2} \mathrm{O}_{3}+\mathrm{J}_{2}=\mathrm{Na}_{2} \mathrm{~S}_{4} \mathrm{O}_{6} 2 \mathrm{NaJ}
$$

Titration was carried out in the presence of an indicator - starch - and was carried out until the solution was discoloured, that is until complete fixation of the free iodine was achieved.

Two molecules of thiosulfate are consumed for each molecule of ozone in the reaction during the titration. Thus, the amount of thiosulfate used during titration is proportional to the amount of ozone reacting, and if the reaction is complete, then the amount of ozone in a gas $(C)$ can be determined by the amount of thiosulfate in accordance with the expression below:

$$
C=E_{0} \frac{V_{m} M_{m}}{V}
$$

where $E_{0}$ is the molar mass equivalent of ozone;

$$
M_{m}\left(\frac{1}{2} \cdot \mathrm{O}_{3}\right)=24 \mathrm{~g} / \mathrm{mol} \text {, }
$$

where $M_{m}$ is the molar concentration of the thiosulfate solution; $V_{m}$ is the volume of the thiosulfate solution used during titration, $\mathrm{ml}$; and $V$ is the volume of a gas that has passed through the solution of thiosulfate, 1.

To normalize the ozone concentration to ambient conditions, it is necessary to measure the atmospheric pressure and the ambient temperature and then calculate the reduced concentration of using the following formula:

$$
C_{o}=C \frac{P_{0} \cdot T}{P \cdot T_{0}},
$$

where $P$ is the atmospheric pressure, $\mathrm{mm} \mathrm{Hg}$;

$P_{0}-760 \mathrm{mmHg}$, normal pressure;

$T$ - ambient air temperature, $\mathrm{K}$;

$T_{0}-293 \mathrm{~K}$ - normal temperature.

The ozone concentration was determined as follows: first, we prepared a solution $\left(13.7 \mathrm{~g} \mathrm{~K}_{2} \mathrm{HPO}_{4}+\right.$ $14.1 \mathrm{~g} \mathrm{NaH}_{2} \mathrm{PO}_{4}$ ) in $1000 \mathrm{ml}$ of $\mathrm{H}_{2} \mathrm{O}$. Then, in contrast to the standard technique, which suggests using a $5 \%$ solution, we prepared a $0.1 \mathrm{~N}$ potassium iodide buffer solution (KI). The ozone-air mixture produced by the installation under study was passed through $40-50 \mathrm{ml}$ of a one-molar solution of potassium iodide (KI). After passing the ozonised gas, the resulting solution was poured into a flask and acidified with $5 \mathrm{ml}$ of a $2 \mathrm{~N}$ solution of $\mathrm{HCl}$. The released iodine was titrated with a $0.01 \mathrm{~N}$ solution of sodium hyposulfite, also prepared from the standard titrimetric substance, to a slightly yellow colour, after which $1 \mathrm{ml}$ of a $1 \%$ starch solution was added, and the titrant was added until the blue colour disappeared. The ozone content was calculated by the following formula:

$$
C=24 \times V \times \mathrm{N} / V,
$$

where $C$ is the ozone content, $\mathrm{mg} \mathrm{l}^{-1}$;

$\mathrm{N}$ is the normality of the hyposulfate solution used for titration, $\mathrm{N}$;

24 is the conversion factor for the moles of sodium hyposulfite to ozone; and

$V$ is the volume of ozonised gas passed through a solution of potassium iodide, 1 .

\section{RESULTS AND DISCUSSION}

In the laboratory of electrical technologies of KubSAU, an experiment was set up to identify the effect of various concentrations and exposures of an ozone-air mixture on the germinating energy of maize seeds. For this experiment, we treated 8 batches of 400 seeds with ozone at a concentration of $32 \mathrm{mg} \mathrm{m}^{-3}$ for different exposure times. Seeds were planted and germinated in accordance with the requirements for determining the sowing qualities of seeds. In addition to the treated seeds, control seeds were planted. With to the results of the experiment, a dependence curve was generated.

After analysing Figure 1, we can conclude that the area of positive effect of ozone on maize seeds lies within 3-9 minutes of exposure time.

To more accurately determine the effect of ozone on the seeds, a full-factor experiment was established.

According to the results of the experiment, the following dependence curve was constructed:

An increase in seedling germination energy was observed in all treatment modes. The seedling germination energy increase at the lowest level of exposure to ozone (X1 - 3 minutes; $\mathrm{X} 2$ - $24 \mathrm{mgm}^{-3}$; X3 - 1 day) was approximately $2 \%$. This suggests an insufficient amount of the ozone-air mixture for full activation of the supply of nutrients inside the seed. However, at the same time, it should be noted that the positive effect of 


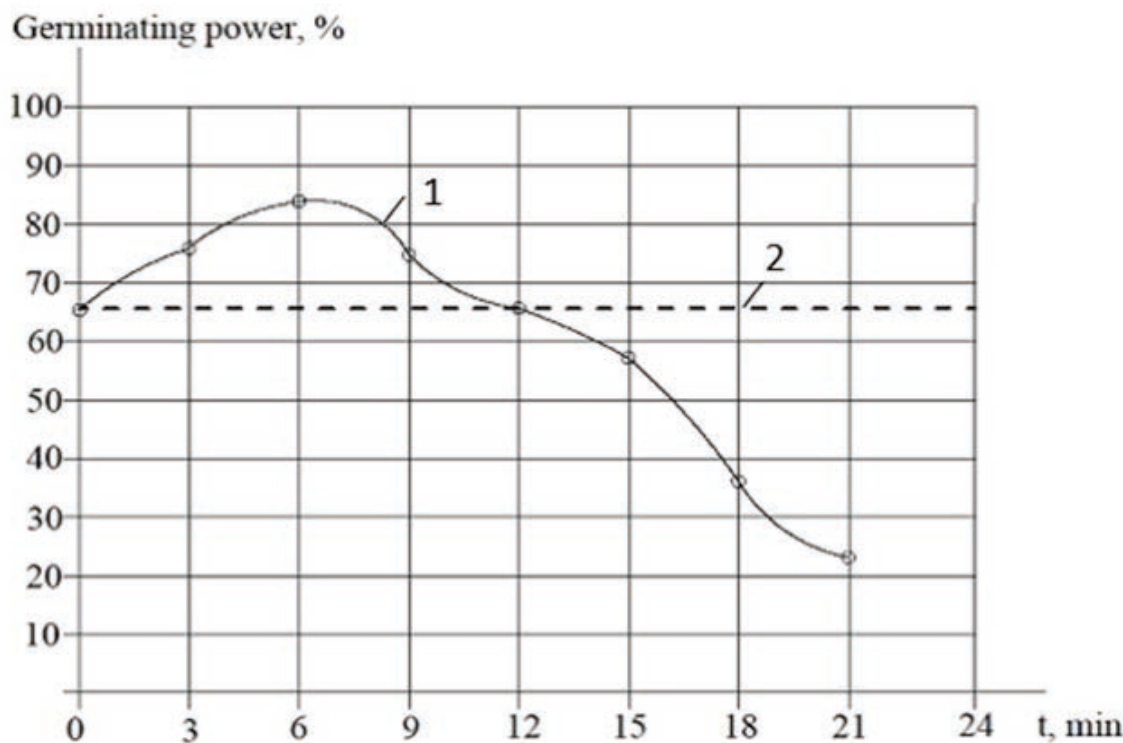

Figure 1: Preliminary experimental data. line 1 - treated seeds; 2 - untreated seeds

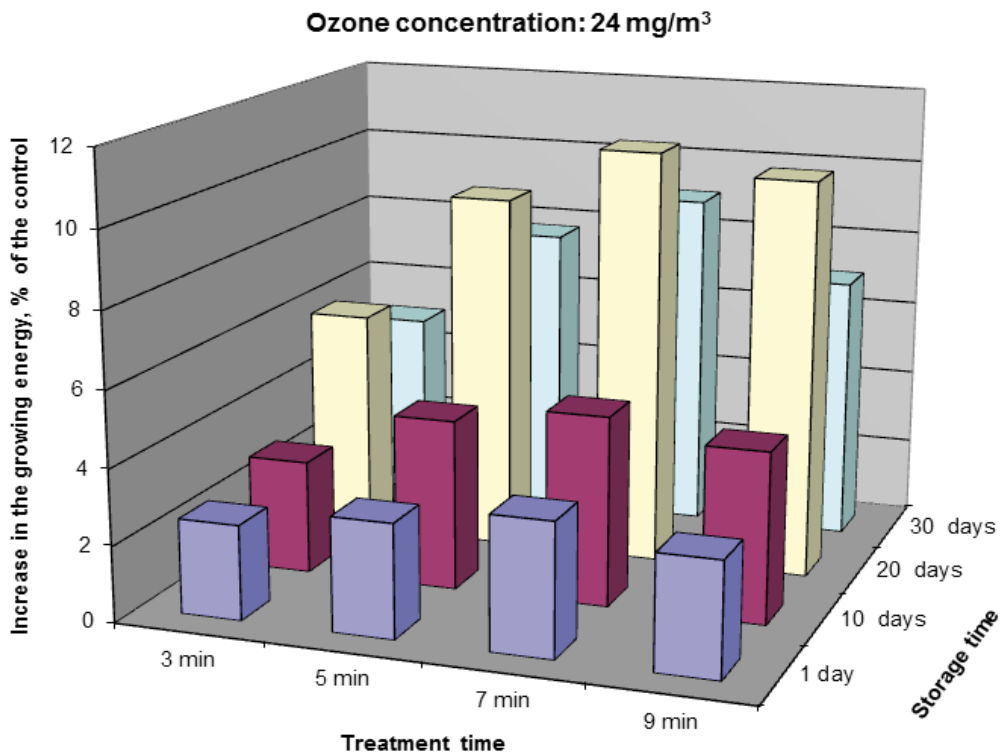

Figure 2: The effect of different ozone treatment modes on maize seeds

the ozone-air mixture on the germination energy began to decline at $\mathrm{X} 1=9$ minutes.

This histogram shows that the most appropriate mode for treating maize seeds was the one in which the treatment time (X1) was 7 minutes and the time before sowing (X3) was 20 days. At this level of treatment, the increase in germination energy compared with that of the control was more than $10 \%$, which indicates an increase in the sowing qualities of seeds.

As the histogram shows, the time before sowing is also an important factor. Thus, at X3 $=1$ day and a treatment time of 7 minutes at a concentration of $24 \mathrm{mg} \mathrm{m}^{-3}$, the germination energy increased by approximately $2 \%$; after 10 days, it was $4.5 \%$; 10 days later, its level rose to $10.5 \%$, and after another 10 days, it began to decline and was $9 \%$. Based on this, we can say that the ozone was completely absorbed by the seed and activated the processes inside the seed in 20 days. This effect was observed in all modes considered in the work. With the help of the computer program "STATIS- 
TICA 6.0", the data were processed, and a multiple regression equation was obtained, as follows:

$Y 1=3.66+0.46 \cdot X 1 X 3+0.40 \cdot X 2 X 3-5.96 \cdot X 33$

$+7.86 \cdot X 32-1.99 \cdot X 3-0.26 \cdot X 1 X 2 X 3-1.23 \cdot X 1-3.7$

$\cdot X 13+4.9 \cdot X 12-1.88 \cdot X 23+1.89 \cdot X 22$.

where $X 1$ - Ozone treatment time of seeds, min;

$\mathrm{X} 2$ - Concentration, $\mathrm{mg} \mathrm{m}^{-3}$;

$X 3$ - Time before sowing, days; and

Y1 - Dependent variable germination energy, \%.

As a result, a close $(\mathrm{r}=0.96)$ correlation between the germination energy and the studied factors was established. It was also found that $92 \%$ of the $Y 1$ variation (germination energy) is "explained" by all $X$ variables.

The shift determines the predicted value of $Y$ when all variables $X$ are equal to 0 . In our case, this $Y$ value was $3.66 \%$ and interpreted as follows: the typical germination energy of an untreated maize seed that was $3.66 \%$.

Regression coefficients were interpreted as the influence of each variable on the value of germination energy if all other independent ("explanatory") variables remain unchanged.

The regression coefficient for the interaction between the grain ozone treatment time and the time before sowing $(\mathrm{b}$ X1X3 $=0.46)$ indicates that, when all other conditions are held constant, the germination energy increases by $0.46 \%$ when the grain treatment time and the time before sowing interact. In addition, when the grain ozone treatment time changes by one unit, germination energy decreases by $1.23 \%$. Thus, an interpretation of all coefficients was made for the variables $X$ in the event that these values are significant (significance level $p<0.05$ ). If the coefficient was insignificant, i.e., $p>0.05$, it was not subjected to interpretation and was removed from the equation because it did not carry additional information to predict the value of germination energy.

Germination ability is one of the most significant indicators of crop yield. An increase in germination ability directly indicates an increase in the final crop yield. Ozone treatment also increases the germination ability due to the activation of the internal energy of seeds without changes at the gene level and due to the disinfection of seeds.

Based on the data obtained in the course of the experiment, a figure was constructed that reflects the effect of the ozone-air mixture on the object under study. Thus, the following figure shows the germination variability depending on the concentration and time before sowing maize seeds of the T22MB variety.

The relations shown in Figure 3 were approximated by the program, so there are negative concentrations and times before sowing shown. It should also be noted that at a concentration equal to zero and a change in the values of time before sowing, an increase in germination ability occurred; this change is associated with the approximation conditions incorporated in the software.

Considering the relations presented in Figure 3, we can say that the most acceptable methods for increasing the germination ability of maize seeds are those in which the ozone concentration ranges from 20 to

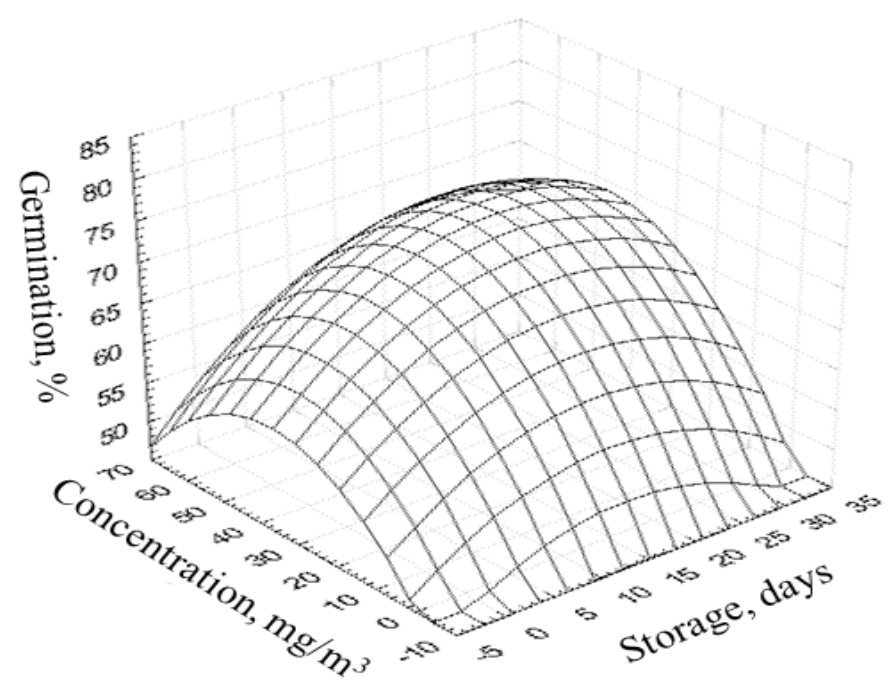

Figure 3: Increased germination ability of maize seeds under the influence of ozone concentration and time before sowing after treatment 
$40 \mathrm{mg} \mathrm{m}^{-3}$ and in which the time before sowing after treatment is 15-25 days. At such conditions, the germination ability was approximately $80 \%$, while the initial germination of the grain was approximately $65 \%$.

It should also be noted that with increasing ozone concentration $X 2$, the germination $Y 2$ begins to decrease. During the experiment, it was noted that seedlings at high doses of treatment had black (burnt) ends. This suggests that the oxidative properties of ozone began to degrade the structure of cells and partially destroyed them at high concentrations. Consequently, with a further increase in concentration, the grain will receive a lethal dose of ozone and will die due to cell destruction.

When $X 2$ is approximately $70 \mathrm{mg} \mathrm{m}^{-3}$ and the treatment time $X 1=5$ minutes, the germination ability was approximately $50 \%$, with a control grain germination rate of $65 \%$. With a further increase in ozone concentration, the germination continued to decrease, and eventually, the maize kernels were killed.

After conducting regression analysis, we obtained the following regression equation:

$$
Y 2=52.9+0.35 X 2 X 3-5.66 X 13-2.49 X 1-0.096
$$

$X 23-2.25 X 22-1.79 X 33+1.5 X 32+0.39 X 1 X 3+7.68$ $X 12+2.66 X 2-0.28 X 1 X 2$.

where Y2 - dependent variable, the germination of maize seeds.

The data obtained indicate a sufficient correlation $(r=0.94)$ between germination ability and the studied factors. At the same time, in $88 \%$ of cases, the factors included in the equation influence germination ability, and $12 \%$ are controlled by other factors that were not taken into account when building the mathematical model.

It should be noted that the coefficients for variable interaction of the grain treatment time with ozone with ozone concentration $(X 1 X 2)$ and the squared (X22) and cubed (X23) concentrations were not significant and could not only be interpreted but could also be removed from the equation due to the absence of effects on grain germination ability. Thus, the equation took the following form:

$$
Y 2=52.9+0.35 X 2 X 3-5.66 X 13-2.49 X 1-1.79
$$
$X 33+1.5 X 32+0.39 X 1 X 3+7.68 X 12+2.66 X 2$.

Considering the equation, we can say that the combination of factors $X 1 X 3$ (treatment time and time before sowing) had the greatest influence on Y2. Their influence was $0.39 \%$ when all other conditions are held constant. This was despite the fact that the treatment time alone $(X 1)$ reduced the treatment efficiency by $2.49 \%$. This suggests that the use of ozone seed treatment without a storage period before sowing is impractical. The combination of factors $X 2 X 3$, similarly to $X 1 X 3$, had an effect on seed germination ability, but the effect in percentage was somewhat smaller $(0.35 \%)$.

Of the single factors, the factors $X 12, X 2$ and $X 32$ had the greatest positive influence, with coefficients of $7.68,2.66$, and 1.5 , respectively.

The remaining factors had a negative effect on the germination ability of maize seeds since the coefficients of the indicators had negative signs.

The growing energy of seedlings determines the degree of their development. Thus, if the plant is underdeveloped, i.e., has a weak root and shoot, it may not achieve maturity of the cob or will do so much later
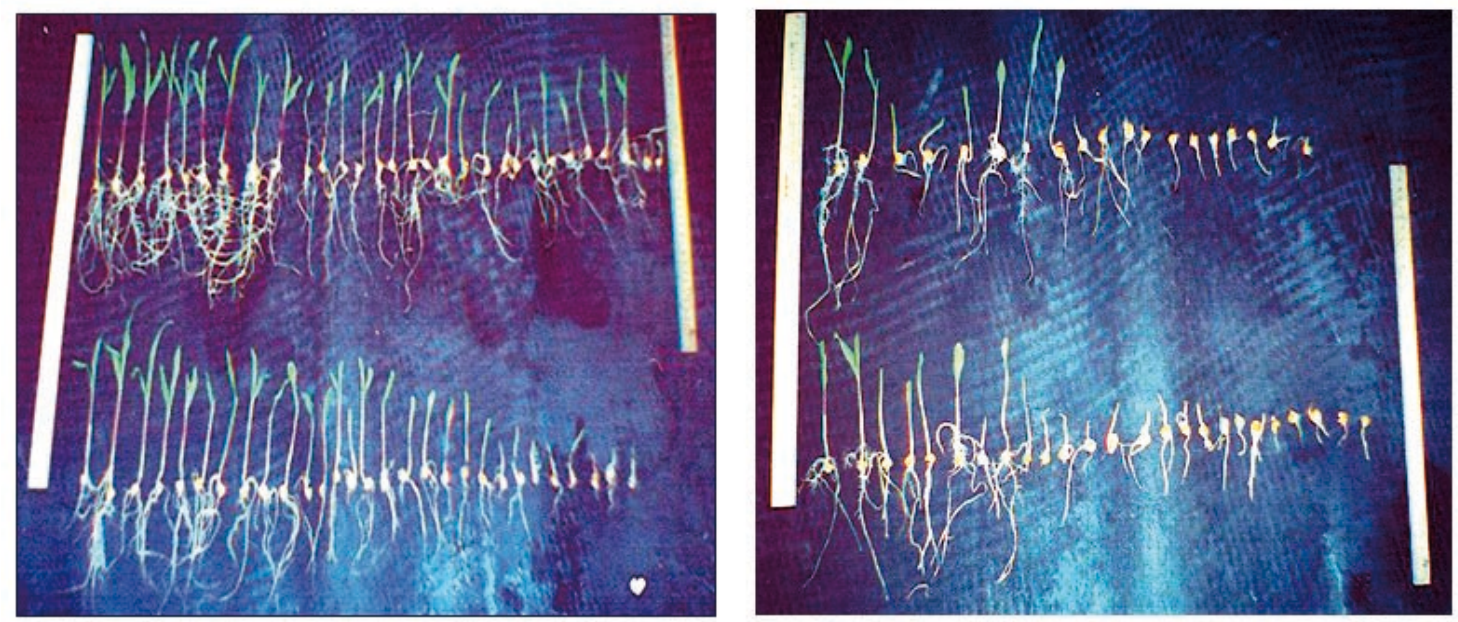

Figure 4: Samples of germinated maize seeds (treated - left; untreated - right) 
than normally developed plants, which is unacceptable because harvesting time is limited by agrotechnical requirements.

Growing energy can also influence the number of cobs on a plant. Therefore, usually one stalk of maize has one cob or two that are underdeveloped. If the growing energy of the plant is high, then the plant will have a decreased vegetative period, and it will be able to gain a larger supply of nutrients before the summer drought, and as a result, it will exhibit improved growth and produce more healthy and developed cobs.

The experiment showed that the treated seeds had a higher growing energy, and, visually, they had a more saturated colour. The root system of the treated seeds was strong and had one long, strong main root (seminal root, approximately $10 \mathrm{~cm}$ ) with small sprouts. The untreated seeds had a root system of approximately $5 \mathrm{~cm}$ in length. Photographs of the germinated seeds are presented in Figure 4.

It is necessary to resort to statistical processing of experimental data to determine the degree of influence of the studied factors on the growing energy of seedlings.

After statistical processing of experimental data, we obtained a multiple regression equation that is expressed below:

$Y 3=23.8+1.77 X 3-1.29 X 33-2.49 X 13+2.37 X 12$ $-4.05 X 23+5.75 X 22-1.0 X 2$.

where $Y 3$ is the dependent variable, growing energy, \%.

A close correlation has been established between the variable factors used and the growing energy of seedlings $-\mathrm{R}=0.91$. In addition, in $84 \%$ of cases, the factors studied had an effect on the growing energy of the seedlings, and in $16 \%$, they were controlled by other factors that were not taken into account during the experiment. Such factors may be the ambient temperature during seed germination, air humidity, composition of water used for watering plants, etc.

A large level of significance was observed for the growing energy indicator $X 22 \mathrm{a}=5.75$. This indicates that when all other indicators are held constant, the growing energy is $5.75 \%$ than that of the control higher due to the performance of seeds after treatment.

According to the data obtained during the experiment, the histogram shown in Figure 5 was constructed.

It can be seen from the graph that the maximum value of the growing energy was reached at an ozone concentration $(X 2)$ of $48 \mathrm{mg} \mathrm{m}^{-3}$, a treatment time (X1) of 5 minutes and a time after treatment and before sowing (X3) of 20 days. With these method parameters, ten typical plants reached $61 \mathrm{~mm}$. This is two times more than with the same treatment mode but no wait time after treatment and before sowing $(28 \mathrm{~mm})$. To construct the graph, we used the data on the length of a maize seed kernel.

With an increase in processing time of more than 5 minutes, there was a decrease in the length of seedlings. For example, when the time before sowing was 10 days, the concentration of ozone was $24 \mathrm{mg} \mathrm{m}^{-3}$, and the treatment time was 5 minutes, the growing energy of the seedlings was $45 \mathrm{~mm}$ (for this experiment we took this indicator in relation to untreated grain). With an increase in treatment time up to 9 minutes, the growing energy decreased and was measured as $37 \mathrm{~mm}$. The same effect was observed at other time levels before

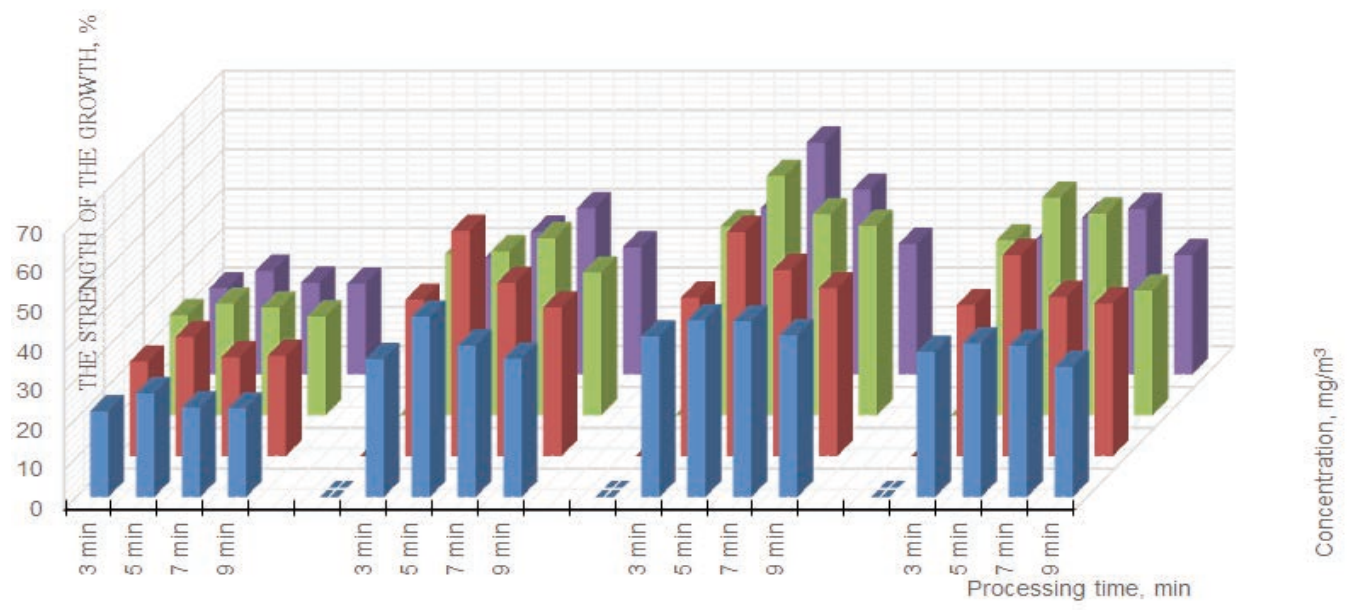

Figure 5: Changes in the growing energy of maize seedlings caused by ozone-air treatment and time before sowing after treatment 
sowing. This suggests an overdose of the ozone-air mixture during treatment.

\section{REFRENCES}

Booker, F.L. (2009). The ozone component of global change: Potential effects on agricultural and horticultural plant yield, product quality and interactions with invasive species, Journal of Integrative Plant Biology, 51, 337-351.

Chizhevsky, A.L. (2015). Earth and space. Earth echo of cosmic storms. Academic project: 272 p. https://doi.org/10.1111/ j.1744-7909.2008.00805.x

Dospehov, B.A. (1985). Methods of field experience: the textbook. Agropromizdat: $351 \mathrm{p}$.

Gerlach K.A. (1995). Effects of ozone on soybean seed vigor. Sustaing Planet Faith. Charleston: 44.

Mendes F., Maier D.E., Mason L.J. and Woloshuk C.P. (2003). Penetration of ozone into columns of stored grains and effects on chemical composition and processing performance. Journal of Stored Products Research, 39, 1, p. 3344. https://doi.org/10.1016/S0022-474X(02)00015-2

Normov, D.A. (2003). Drying and bactericidal properties of ozone. Physical and technical problems of creating new technologies in the agro-industrial complex: Collection of scientific papers. SSAU, Stavropol: 219-220.
Pat. 2248111 Russian Federation, IPC A01 S1 / 00 Method of presowing treatment of agricultural crops / Normov, D.A., Oskin S.V., Shevchenko A.A., Saprunova E.A./ applicant and patentee of KubSAU. - № 2003123158/13; declare 07/22/03, publ. 03/20/05, Bull. № 23: 3 p.

Rezchikov V.G., Churmasov, A.V., Gavrilova, A.A. (1998). The effect of ozone on the germination of pea and sea-buckthorn seeds. Technics in agriculture. Chelyabinsk: 14-17.

Sun J, Feng Z, Ort DR (2014) Impacts of rising tropospheric ozone on photosynthesis and metabolite levels on field grown soybean. Plant Science, 226, 147-161. https://doi. org/10.1016/j.plantsci.2014.06.012

Tzortzakis, N. G., Taybi, T., Antony, E., Singleton, I., Borland, A., \& Barnes, J. (2013). Profiling shifts in protein complement in tomato fruit induced by atmospheric ozone-enrichment and/or wound-inoculation with Botrytis cinerea. Postharvest Biology and Technology, 78, 67-75. https://doi. org/10.1016/j.postharvbio.2012.12.005

Voznesensky V.A. 1981. Statistical Methods for Experimental Planning in Techno-Economic Research. Finance and Statistics: 259 p.

Yeoh, W. K., Ali, A., \& Forney, C. F. (2014). Effects of ozone on major antioxidants and microbial populations of freshcut papaya. Postharvest Biology and Technology, 89, 56-58. https://doi.org/10.1016/j.postharvbio.2013.11.006 